\title{
Effects of Sewage Sludge and Endo- mycorrhizal on Growth, Chemical Content and Some Physical Properties of Swietenia mahagoni seedling
}

\author{
Abd El-Kader, M. M. E . ${ }^{1}$; Naglaa, K. Abo-Eleil ${ }^{1}$; Abo- Elsoud, I.H ${ }^{2}$. \\ ${ }^{1}$ Forstry Department, Horticulture Research Institute, Agriculture Research Center, Egypt \\ ${ }^{2}$ Suez Canal University, Faculty of Agriculture, Department of Horticulture, P.O. Box 41522, Ismailia, Egypt, \\ "Corresponding author: Islamhassan2010@agr.suez.edu.eg or Islamhassan2010@ hotmail.com
}

\begin{abstract}
This work was carried out during two seasons of 2012/2013 and 2013/2014 in the agricultural research center in El Khassasen. The aim of the this study was to investigate the effect of arbuscular mycorrhizal (AM) fungi inoculation with sewage sludge on the growth of Swieteina mahagoni, seedlings. The AM fungi were used as a mixed culture from species of Glomus mosseae, G. etunicatum and G. clarum..The factorial pot experiment was designed in six amount from sewage sludge (control, 250, 500, 750, 100 and $1250 \mathrm{~g}$ plant ${ }^{1}$ ) with four levels of AM fungi (zero, 150, 300 and $450 \pm 10$ spores plant ${ }^{-1}$ ). The results shown that, the maximum values in all plant growth parameter were recorded in the plant treated with 500g sewage sludge with AM fungi inoculation rate300, 450 spores/ plant and NPK \% in plants leaves was obtained from 500g with 300 and450spores/plant of AM fungi inoculation. The maximum amount of plant chlorophyll $\mathrm{a}$, chlorophyll $\mathrm{b}$ and carotenoids were found at plants treated with AM fungi by rate 300 spores/ plant with 500g sewage sludge. The addition of AM fungi to sewage sludge had better growth effect and NPK uptake when comparison between treatments. This is due to the mutual positive action of S. mahagoni and AM fungi species that helped to absorb more NPK fertilization from soil.
\end{abstract}

Key Words: Woody trees, AM fungi, Bio-fertilization, Mahogany, sewage sludge

\section{Introduction}

Swietenia mahagoni (L.) Jacq, is one of the most highly valued timbers in the world, belong to Family Meliaceae. S. mahagoni is a tall tree, up to $30 \mathrm{~m}$ high, with a short, buttressing base, up to $1 \mathrm{~m}$ in diameter and a large, spherical crown, many heavy branches and dense shade. (Orwa et al., 2009; Sahgal et al., 2009; Panda et al., 2010 and Bhurat et al., 2011). Sewage sludge a product of wastewater is a valuable fertilizer which can be beneficially applied to many crops. Its use in agriculture as well, but it is comparatively recently that its potential as a forest fertilizer has been recognized Kouloumbosa et al., (2008). Trees are suitable for sludge amended soils because they are not significant food source (and because of their large biomass). (Spinosa, 2007) .Vesicular-arbuscular mychorrhizae (VAM) are phycomycetous fungi belong to the order Glomerales, family Glomeraceae and class glomeromycetes. The genera that contain species known to from VAM are Glomus, Gigaspora, Acaulospora, Sclerocystis and Entrophospora (Trappe, 1982). The plants form symbiotic association with VAM which penetrate the root and form characteristic arbuscules and vesicules within the cortex. The aim of this experiment was to evaluate sewage sludg at six rate (control "wihou" ,
$250,500,750,1000$ and 1250 (g/plant) besides four quantities of endo -mycorrhiza fungi under sandy soil condition.

\section{Materials And Methods}

The experiments were carried out at El-Kassasin Horticultural Research Station, Egypt. During two successive seasons of 2012/2013 and 2013/2014.

\section{Plant materials :}

One year old transplants of Swietenia mahagoni (L.) Jacq were brought from the Horticultural Research Institute nurseries. The measurements of seedlings averaged $30 \mathrm{~cm}$. in height and $0.35 \mathrm{~cm}$ in diameter ( at $5 \mathrm{~cm}$. above ground). Seedlings were grown in poly bags $40 \mathrm{~cm}$ in diameter, when open 45 $\mathrm{cm}$ in height in 15th of March 2012 and 2013 seasons. Each bag contains $20 \mathrm{~kg}$.of sandy soil.

\section{Sewage sludge treatments}

The sewage sludge bulk samples were taken from Ismailia Waste Water Treatment Plant (I.W.W.T.P.) at Sarabium. The chemical analysis of the sewage sludge was carried at the table (1). Seedlings were treated with sewage sludge (zero,250,500,750,1000 and $\left.1250 \mathrm{~g} \mathrm{pot}^{-1}\right)$. 
Table 1. Chemical analysis of the sewage sludge from Ismailia waste water station Preparation of mycorrhizal inoculums

\begin{tabular}{lclc}
\hline & Sewage sludge & & \\
\hline Parameter & Value & Total heavy metals (ppm) \\
\hline Organic matter & $23.69 \%$ & $\mathrm{Fe}$ & 94.50 \\
Organic carbon & $12.26 \%$ & $\mathrm{Mn}$ & 170.00 \\
Total nitrogen $(\mathrm{N})$ & $2.75 \%$ & $\mathrm{Zn}$ & 254.00 \\
C/N ratio & $6.81 \%$ & $\mathrm{Cu}$ & 750.00 \\
Available phosphorus (p) & $0.46 \%$ & $\mathrm{Cd}$ & 3.00 \\
Total potassium (K) & $0.13 \%$ & $\mathrm{Ni}$ & 45.00 \\
pH $(1: 2.5$ sludge : water) & 7.5 & $\mathrm{~Pb}$ & 201.06 \\
E. C. $(1: 1$ sludge : water. $\mathrm{d} \mathrm{s} / \mathrm{m})$ & 3.8 & & \\
\hline
\end{tabular}

The AM fungi were used in this study as a mixed culture from species of Glomus mosseae G. clarum $27 \%$ supplied from microbiology Lab. Faculty of Agriculture, Suez Canal University, Ismailia, Egypt. The inoculums were calculated based on number of spores present in $1 \mathrm{~g}$ of dry roots (150 spore's $\left.\mathrm{g}^{-1}\right)$. The inoculums prepared in three levels Low (150 spores plant $\left.{ }^{-1}\right)$, medium (300 spores plant $\left.^{-1}\right)$ and High (450 spores plant ${ }^{-1}$ ) in addition to the fourth level which included $1 \mathrm{~g}$ autoclaved dry root as a check treatment (zero spores $\mathrm{g}^{-1}$ ).

\section{Seedlings irrigation}

It was determining the amount of irrigation water based on field capacity of the soil. Each seedling was irrigated two times weekly in summer and one time weekly in winter using $2000 \mathrm{ml}$ (tap water)

\section{The following data were recorded:}

\section{Vegtative growth}

Height increment:The measurement was done twice (at planting time, and end of season) to calculate the annually height increment $\%$ of seedlings

Diameter increment \% of stem at a height $5 \mathrm{~cm}$ : The stem diameter measure was done twiceat planting time and the end of season

Fresh and dry weight of tree portions: Fresh weight of roots, stem, and leaves were calculated by weighting each portion individually then those portions were drayed at $72{ }^{\circ} \mathrm{C}$ to the oven till constant weight and dry weight of each portion was recorded for each treatment in both two seasons.( landolt and Kandeler, 1987).

\section{Chemical continent}

\section{Mineral contents in dried leaves.}

Nitrogen in plant samples were determined by Kjeldahl.Phosphorus concentration in plant leaves was determined by the molybdate blue ascorbic acid method.Potassium was determined according to the procedure described by Mazumdar and Majumder (2003) .
Same heavy metals: $\mathrm{Cd}, \mathrm{Ni}$ and $\mathrm{Pb}$ were measured by Atomic Absorption Spectrophotometer (Page et al., 1982)

\section{Pigments determinations:}

Chlorophyll a, b and carotenoids content in the fresh leaves Chlorophyll a, b and carotenoids were extracted from representative samples using acetone $85 \%$. The optical density of the samples was then measured at wavelength 662, 644 and $440.5 \mathrm{~nm}$ using a Beckman Dk-2 spectrophotometer.

\section{Wood properties}

Moisture content \%: The strip assigned for moisture content was weighted immediately after cutting, oven dried at $103 \pm 2{ }^{\circ} \mathrm{C}$ to constant weight. Moisture content for the disk before machining and moisture content of strip after drying was considered the moisture content of the:

$$
M C=\frac{\text { wtf }- \text { wtd }}{\text { wtd }} \times 100
$$

Where MC = Moisture content, wtf = Fresh weight and wtd $=$ Dry weight

\section{Specific gravity $\mathbf{g} / \mathrm{cm}^{3}$}

Specific gravity was determined based on the fresh volume and oven - dry weight. The volume was determined by water displacement according to American Standard Testing Methods (ASTMD. 1989)

$$
\mathbf{S G}=\frac{\mathrm{OD}}{\mathrm{V}}
$$

Where: $\mathbf{S G}=$ Specific gravity, $\mathbf{O D}=$ Oven dry weight, $\mathbf{V}=$ Volume of sample

\section{Statistical analysis:}

A factorial experiment with three replicates, one seedling in each replicate Data for each experiment was statistically analyzed using computer program (SPSS version 8) copyright by SPSS Inc. 1989-1997 Significant differences among the mean of different 
treatments were carried out by Dancan's multiple range test (Sndecor and Cochran 1967).

Results

\section{Vegtative growth}

Height increment \% of seedlings: Data presented in Table (2) shows that ,The highest mean value of height increment was obtained from $500 \mathrm{~g} / \mathrm{plant}$ for first and second seasons, (88.21 and 102.22\% respectively. The highest significant mean value was recorded at plant treated with 300 spores/ plant AM fungi on the first season by rate $71.51 \%$ and $77.98 \%$ for second season. Sewage sludge at $500 \mathrm{~g} / \mathrm{plant}$ gave the tallest seedlings $(99.83 \%$ and $123.65 \%$ respectively) during the first and second seasons respectively with 300 spores/plant of AM fungi.

Diameter increment\% for seedling stem at height 5cm: Highest mean value $(105.66 \%$ and $147.24 \%$ ) in both season was recorded from $500 \mathrm{~g} / \mathrm{plant}$. The highest mean value $(84.27 \%$ and $113.87 \%$ ) was obtained at300 spores/ plant in first season and second season. AM fungi at 450 spores /plant with 500g/plant gave highest mean value 117.17 and $165.62 \%$ on both seasons respectively. Table (2)

Fresh weight of leaves: The higher mean value of leaves fresh weight $40.79 \mathrm{~g} / \mathrm{plant}$, which was recorded at $500 \mathrm{~g} / \mathrm{plant}$ on the first season. Also from, $500 \mathrm{~g} /$ plant the large mean value $44.66 \mathrm{~g} / \mathrm{plant}$ of leaves fresh weight in second season. The effect of endomycorrhizal on fresh weight of leaves, indicated that, the highest mean value obtained from 300 spores/plant for first and second seasons 33.97and $34.79 \mathrm{~g} /$ plant respectively . On the other hand the 450 spores/plant of endo -mycorrhizal with $500 \mathrm{~g} /$ plant of sewage sludge recorded the heaviest mean value on $69.70 \mathrm{~g} /$ plant and $34.13 \mathrm{~g} / \mathrm{plant}$ for first season and second season respectively.

Fresh weight of stem: Data presented in Table (3) showed that, the highest mean value on fresh weight of stem was obtained from $500 \mathrm{~g} /$ plant of sewage sludge (66.83 g/plant and $59.26 \mathrm{~g} /$ plant $)$ on both seasons respectively. Endomycorrhizal fungi treatments were generally increased the fresh weight of stem and this effect reached the higher mean value $54.81 \mathrm{~g} /$ plant and $52.21 \mathrm{~g} /$ plant with 300 spores/plant in both second seasons., the sewage sludge as $500 \mathrm{~g} /$ plant with 450 spores/plant of AM fungi for both seasons were gave the large mean value (70.50/plant and $68.33 \mathrm{~g} /$ plant respectively) on fresh weight of stem.

Fresh weight of root: Data showed, that the sewage sludge treatment by $500 \mathrm{~g} / \mathrm{plant}$ was produced the largest mean value (24.16g/plant and 21.26/plant) for both seasons. The plant was treated by 450 spores/plant recorded a largest mean value (24.36 $\mathrm{g} /$ plant and $18.13 \mathrm{~g} / \mathrm{plant})$ on both seasons respectively. The sewage sludge at 500g/plant recorded higher mean $(26.83 \mathrm{~g} / \mathrm{plant}$ and $25.60 \mathrm{~g} /$ plant) with mycorrhial fungi 450 spores/plant of AM fungi on first season and second season.

Dry weight of leaves Data presented in Table (4) indicate that, the higher mean value $(30.79 \mathrm{~g} / \mathrm{plant}$ and $12.01 \mathrm{~g} / \mathrm{plant}$ ) obtained from addition $500 \mathrm{~g}$ sewage sludge on both seasons and showed that planted treated with300spores/plant gaves the highest value $(23.97 \mathrm{~g} / \mathrm{plant}$ and $8.60 \mathrm{~g} / \mathrm{plant})$ during the two seasons. However, sewage sludge at $500 \mathrm{~g} / \mathrm{plant}$ with 300 spores/plant of AM fungi gave the highest mean value $(34.33 \mathrm{~g} / \mathrm{plant}$ and $12.33 \mathrm{~g} /$ plant $)$ on first season and second season.

Dry weight of stem: The highest mean value $(54.83 \mathrm{~g} /$ plant and $47.77 \mathrm{~g} /$ plant $)$ of was obtained from $500 \mathrm{~g}$ sewage sludge during both season respectively .Also, the largest mean value $(42.80 \mathrm{~g} /$ plant and $40.52 \mathrm{~g} / \mathrm{plant})$ recorded with 300 spores/plant during tow season respectively.. However, 450spores/plant of AM fungi with $500 \mathrm{~g} /$ plant gave the highest values $60.33 /$ plant and $54.33 \mathrm{~g} /$ plant for two second season. Table (4)

\section{Dry weight of root (g/plant) of seedlings}

Data in Table (4) shows that, seedling that has been trated by $500 \mathrm{~g} / \mathrm{plant}$ of sewage sludge gave the highest mean value $(12.16 \mathrm{~g} / \mathrm{plant}$ and $12.68 \mathrm{~g} / \mathrm{plant})$ respectively at both seasons. The 300 spores/plant of AM fungi gave the largest mean value (12.36/plant and $10.25 \mathrm{~g} / \mathrm{plant}$ ) on both seasons. The AM fungi at300spores/plant of with $500 \mathrm{~g} /$ plant recorded higher mean value $14.83 \mathrm{~g} / \mathrm{plant}$ and $15.93 \mathrm{~g} /$ plant on dry weight of root on two respectively.

\section{Mineral contents in dried leaves \\ Nitrogen \%:}

table (5) indicates that the highest percentage value for the nitrogen was produced from $250,500,750 \mathrm{~g} /$ plant of sewage sludge as $2.15 \%$ and in the second season from $500 \mathrm{~g} /$ plant of sewage sludge as $2.33 \%$.The highest percentage value $(2.12$ $\%$ and $2.03 \%$ ) record from 450 spores/plant in both seasons . the 300 spores/ plant of AM fungi with $500 \mathrm{~g} /$ plant of sewage sludge obtained the highest percentage value $(2.55$ and $2.58 \%)$ in both season from.

\section{Phosphorus \%:}

Data in table (5) it was no different between sewage sludge treatment in first season. Higher Phosphorus percentage value $0.58 \%$ recorded with $500 \mathrm{~g} /$ plant sewage sludge on second season. No differences on effects of AM fungi levels in first season. AMfungi at 300 and, 450spres/ plant gives the highest concentration of phosphorus in second season $(0.0 .46 \%$ and $0.48 \%)$.In general, $500 \mathrm{~g} / \mathrm{plant}$ with 450spores/plant of AM fungi were the best to increase the concentration of phosphorus $(0.49 \%$ and 
0.68 respectively) in the leaves of seedlings in both seasons.

\section{Potassium \%}

Resulted in table(5) indicates that the highest percentage value for the potassium was produced from $500 \mathrm{~g} /$ plant as $0.82 \%$ and $0.77 \%$ in both second season. The best treatment that showed a high value for the increase potassium percentage is treatment 300 spores/plant during both season $(0.71 \%$ and $0.72 \%$ respectively). As for interaction effect, However, 500g/plant with 300spores/plant of AM fungi gave the highest mean value $(0.94 \%$ and $0.86 \%$ ) on first season and second season respectively.

Chlorophyll a (mg/ g FW)Table (7) showed that, the treatment at $500 \mathrm{~g} /$ plant gave highest value 1.77 and 2.02 in both seasons. Also, indicated that, the highest significant mean value1.73and $1.77 \mathrm{of}$ chlorophyll a from 300spores/plant fungi levels. The large mean value (2.07and 2.08) recorded from $500 \mathrm{~g} /$ plant under 300 spores/plant on first season and second season.

Chlorophyll b (mg/ g FW): Tabulated results in table (6) showed that, sewage sludge recorded higher mean value ( 0.83 and 0.69 ) at $500 \mathrm{~g} /$ plant of sewage sludge on two seasons. On the first season, 300 and 450 spoers/plant of AM fungi gave higher mean value $(0.82$ and $0.84 \%)$ and highest mean value $(0.60$ and.62\%.) in second season. AM fungi at 300 spores/plants with $500 \mathrm{~g} /$ plant of sewage sludge the heaviest mean value $(0.91$ and 0.71$)$ of chlorophyll $b$ during both seasons respectively.

Carotenoids (mg/ g FW): Sewage sludge treatment indicated the highest mean value ( 2.32 and 2.25) was obtained from $500 \mathrm{~g} / \mathrm{plant}$ during tow season. .The largest mean value (2.21 and 2.26) recorded with 300 spores/ plant in both seasons. However, 300 spores/plants of AM fungi with $500 \mathrm{~g} /$ sewage sludge the highest values $(2.41$ and $2.37 \%)$ for first season and second season.

\section{Heavy metals on leaves and root}

Data indicted in Table (7) show the effect of different levels sewage sludge and AM fungi on concentration of some heavy metals on leaves and root. The highest value of $\mathrm{Pb}(56.04 \mathrm{ppm})$ on leaves gives from high level of AM fungi and $1250 \mathrm{~g}$ sewage sludge on leaves. On root the largest value recorded from medium level of AM fungi with $1250 \mathrm{~g}$ sewage sludge. On the other hand, the highest concentration of $\mathrm{Ni}$ gives on leaves from medium level of $\mathrm{AM}$ fungi with $1000 \mathrm{~g}$ sewage sludge and from high level with $1000 \mathrm{~g}$ of sewage sludge on root. Also, the large amount of $\mathrm{Cd}$ obtain from $1250 \mathrm{~g}$ sewage sludge with high level (450 spores

\section{Wood properties:}

Moisture content of stem \% : Table (8) shows that, the resulted indicted that, the highest mean value 46.36 and $37.43 \%$ of moisture content with control plants on both seasons. The largest mean value 40.44 and $29.69 \%$ moisture content of recorded with untreated seedlings in two season Also, indicated that, untreated plants of AM fungi with control plant recorded the heaviest mean value 64.61 and $41.73 \%$ of moisture content during two season.

Specific gravity of stem $\left(\mathbf{g} / \mathrm{cm}^{3}\right)$ : Resulted indicted that, 300spores/ plant gave the largest mean value 0.36 and 0.46 of specific gravity of stem at first and second season In general, treated plants with 450spores/plant of AM fungi gave the highest value on first season but on second season, it was significantly differs with treatments and $500 \mathrm{~g}$ sewage sludge/plant under450spores/plant gave biggest mean value $0.53 \mathrm{~g} / \mathrm{m}^{3}$ of specific gravity. Table (8)

\section{Discussion}

The successful association between plants and AM fungi constitutes a strategy to improve the nutritional status of both associates and reduces the use of fertilizers specially phosphorus nutrition (Almagrabi and Abdelmoneim, 2012). Mycorrhizal symbioses facilitate plant uptake of nutrient resources and water (Allen, 1991, Newsham et al., 1995, Zobel et al., 1997). Most studies have investigated $\mathrm{P}$, but mycorrhizas have been implicated in the uptake of most essential nutrients. Plants colonized by AM fungi have greater ability to absorb nutrients like $\mathrm{P}, \mathrm{N}, \mathrm{K}, \mathrm{Ca}$ and $\mathrm{Mg}$ which results in better survival under stressed conditions (Auge and Stodola, 1990). A notable exception is the element boron which is often the main micronutrient limiting growth in soil (Dell and Malajczuk, 1994; Marschner and Dell, 1994; Clark and Zeto, 2000). Dried sewage sludge can be useful in stimulating seedling growth for the reclamation of nutrient deficient sites. Such increase might reflect the improvement of sandy soil characters (physiological, biological and chemical properties) as well as increase of available water and nutrients by increasing organic matter, which cause an increase in the vegetative growth of plants. In conclusion, the results obtained explain that increasing plant growth, mineral content and some wood properties was recorded at plants treated with sewage sludge with AM fungi inoculation. The results are in agreement with El-Baha (2001), Ya et al (2001), Carlot et al., (2002) and Bose et al., (2008), they found the similar results on plant growth.

\section{Recommendation:}

It could be concluded that the addition of Endomycorrhizal fungi rates by 300 and 450 spores of plant with the $500 \mathrm{~g} / \mathrm{plant}$ of sewage sludge for sandy soil increased the vegetative growth ,chemical content and physical properties of Swietenia mahagani seedling 
Table 2. Effects of interaction between sewage sludge and inoculation by endomycorrhizal fungi on height increment\% and diameter of Swietenia mahagoni seedlings during the two seasons (2012-2013) and (2013-2014)

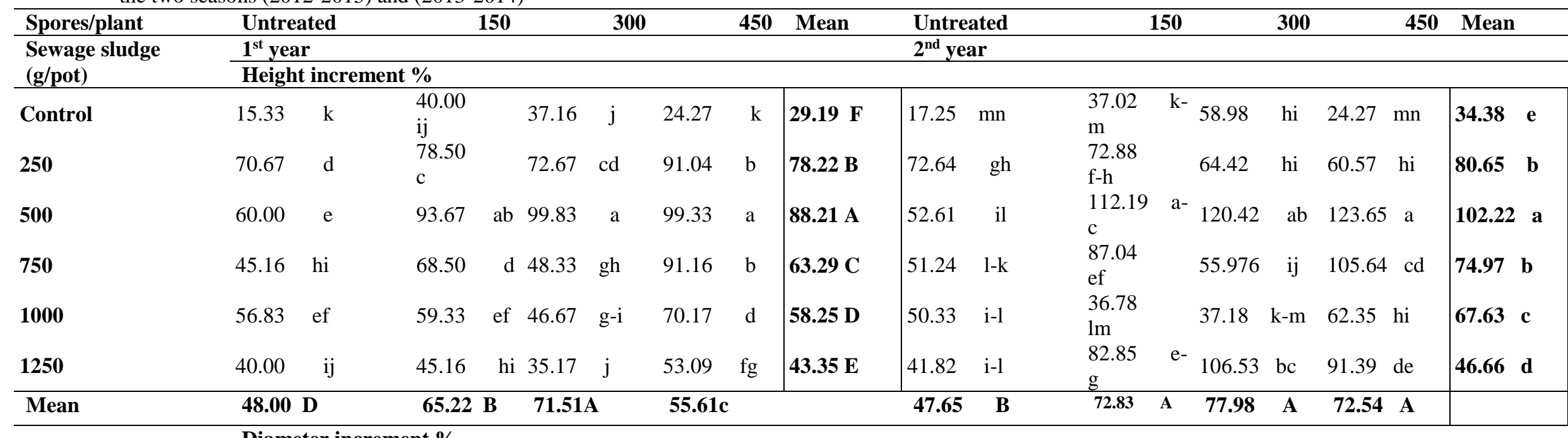

\begin{tabular}{|c|c|c|c|c|c|c|c|c|c|c|c|c|c|c|c|}
\hline & Diame & ter i & nt $\%$ & & & & & & & & & & & & \\
\hline Control & 25.00 & $\mathrm{n}$ & 56.00 & $\mathrm{kl}$ & $51.50 \mathrm{~lm}$ & 35.83 & $\mathrm{n}$ & $42.08 \quad E$ & 67.32 & $\mathrm{ij}$ & $\begin{array}{l}48.53 \\
k\end{array}$ & 51.98 & $\mathrm{k}$ & $60.64 \mathrm{jk}$ & 57.12 \\
\hline 250 & 79.66 & g & 87.67 & f & $107.33 \mathrm{~b}$ & 94.50 & ef & 94.5 & 97.92 & ef & $\begin{array}{l}71.90 \\
\text { ij }\end{array}$ & 122.32 & $\mathrm{c}$ & $106.11 \mathrm{de}$ & $111.55 \mathrm{~B}$ \\
\hline 500 & 92.00 & ef & $\begin{array}{l}106.17 \\
\text { bc }\end{array}$ & & $116.17 \quad \mathrm{a}$ & 117.17 & $\mathrm{a}$ & 105.6 A & 126.47 & $\mathrm{c}$ & $\begin{array}{l}152.21 \\
\mathrm{ab}\end{array}$ & 144.65 & b & $165.62 \mathrm{a}$ & $147.24 \mathrm{~A}$ \\
\hline 750 & 103.00 & $b-d$ & 98.50 & de & 99.33 c-e & 107.83 & b & 102.16 A & 106.02 & de & $\begin{array}{l}118.56 \\
\mathrm{~cd}\end{array}$ & 69.12 & $\mathrm{ij}$ & $140.65 \mathrm{~b}$ & 108.59 B \\
\hline 1000 & 62.50 & $\mathrm{jk}$ & 76.83 & gh & $69.17 \quad \mathrm{ij}$ & 62.83 & $\mathrm{jk}$ & $67.83 \mathrm{C}$ & 77.91 & $\mathrm{~g}-\mathrm{i}$ & 68.86 & 73.82 & $h-j$ & $88.34 \mathrm{fg}$ & $99.56 \mathrm{C}$ \\
\hline 1250 & 71.50 & hi & 58.83 & $\mathrm{kl}$ & $62.17 \mathrm{jk}$ & 47.67 & $\mathrm{~m}$ & & 86.07 & $f-h$ & $\begin{array}{l}92.48 \\
\text { f }\end{array}$ & 145.80 & b & $121.83 \mathrm{c}$ & 77.23 D \\
\hline Mean & 72.27 & $\mathbf{C}$ & 80.66 & B & $\begin{array}{ll}84.27 & \text { A }\end{array}$ & 77.63 & B & & 93.62 & C & $92.09 \mathrm{C}$ & 113.87 & $\mathbf{A}$ & $101.28 \mathrm{~B}$ & \\
\hline
\end{tabular}


Table 3. Effects of interaction between sewage sludge and inoculation by endomycorrhizal fungi on fresh weight (FW) of leaves, stem and root of Swietenia mahagoni seedlings during the two seasons (2012-2013) and (2013-2014)

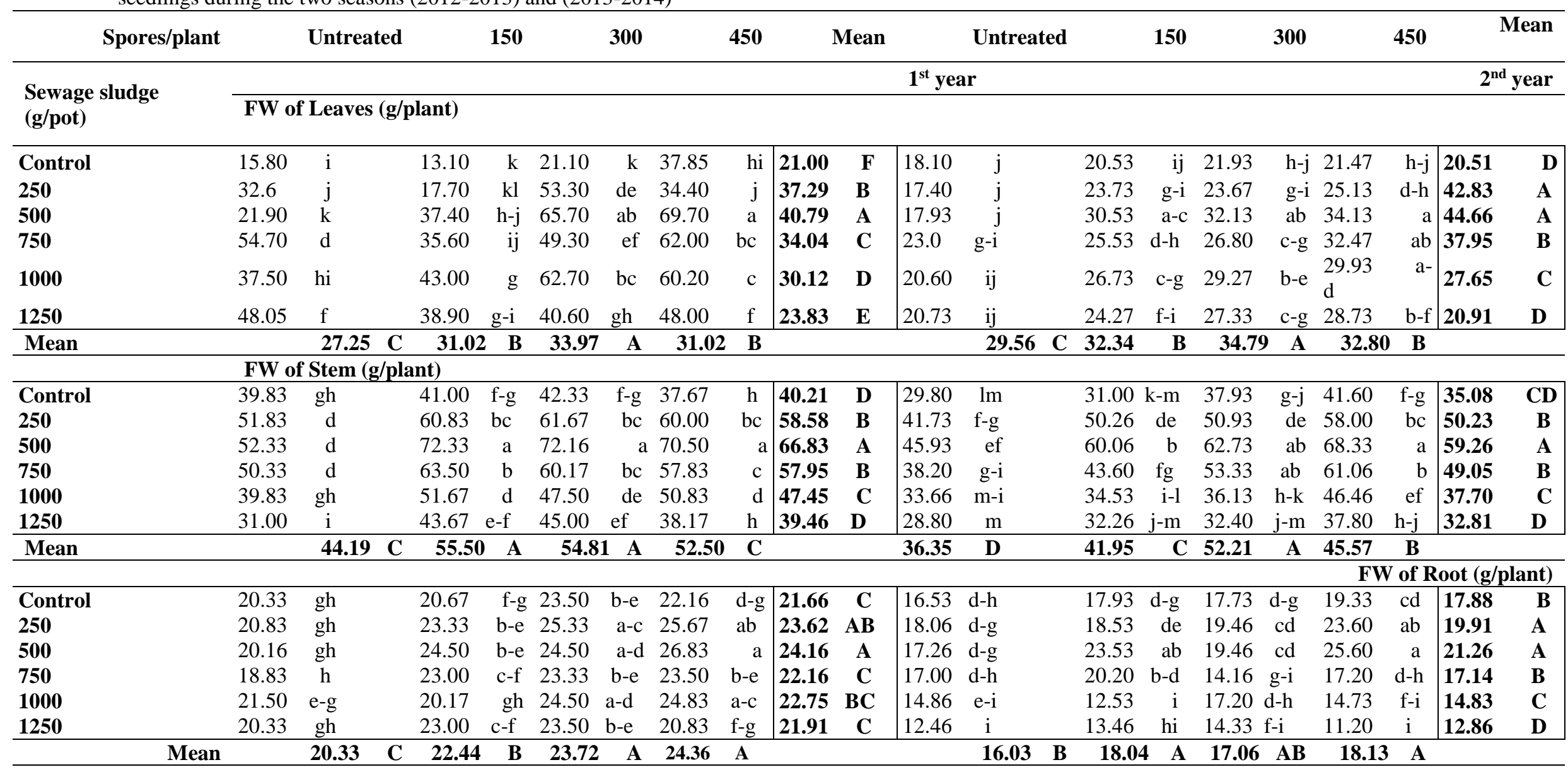


Table 4. Effects of interaction between sewage sludge and inoculation by endomycorrhizal fungi on Dry weight (DW) of leaves, stem and root of Swietenia mahagoni seedlings during the two seasons (2012-2013) and (2013-2014)

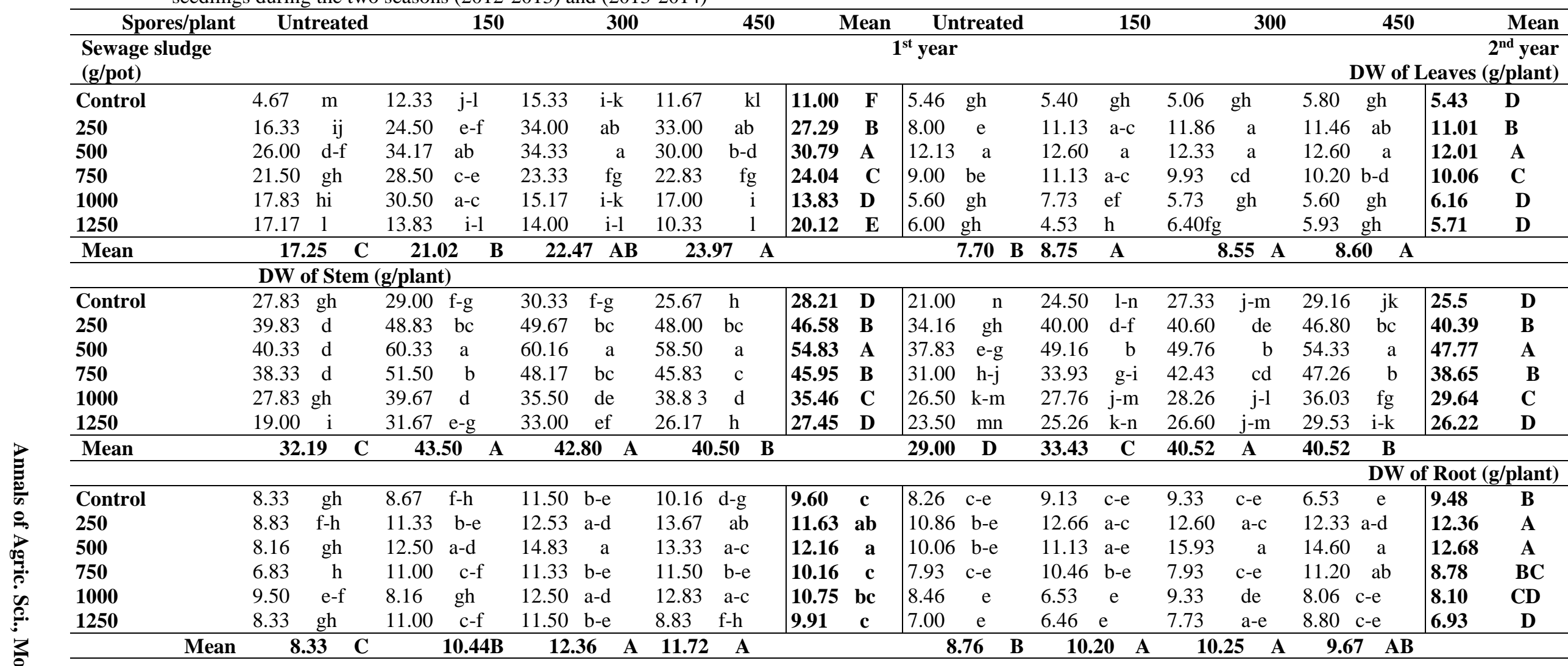


Table 5. Effects of interaction between sewage sludge and inoculation by endomycorrhizal fungi on nitrogen $\%$, phosphorus $\%$ and Potassium $\%$ contents on leaves of Swietenia mahagoni seedlings during the two seasons (2012-2013) and (2013-2014)

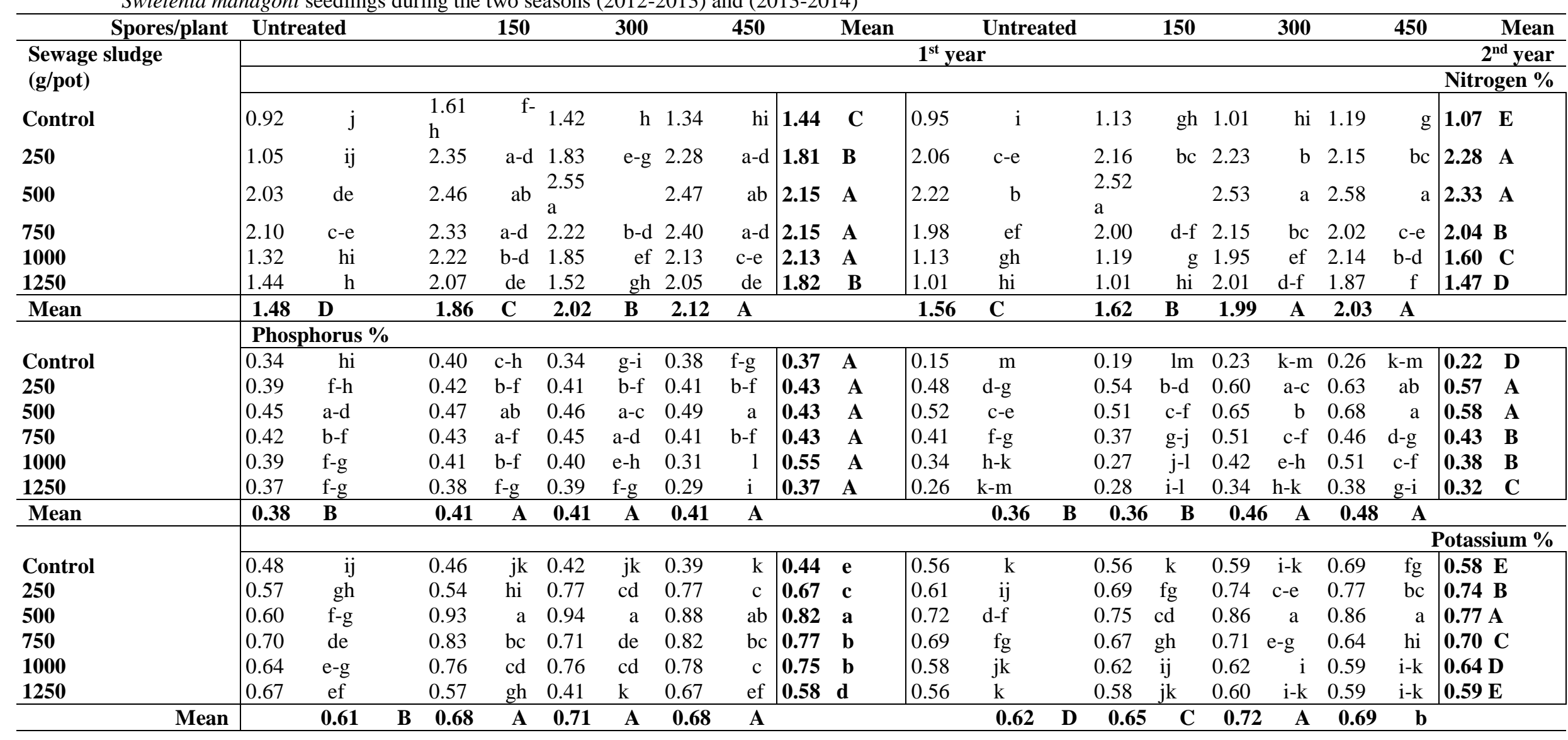




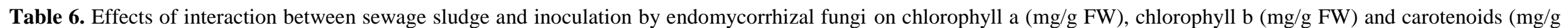
FW) content on leaves of Swietenia mahagoni seedlings during two seasons (2013-2013) and (2013-2014)

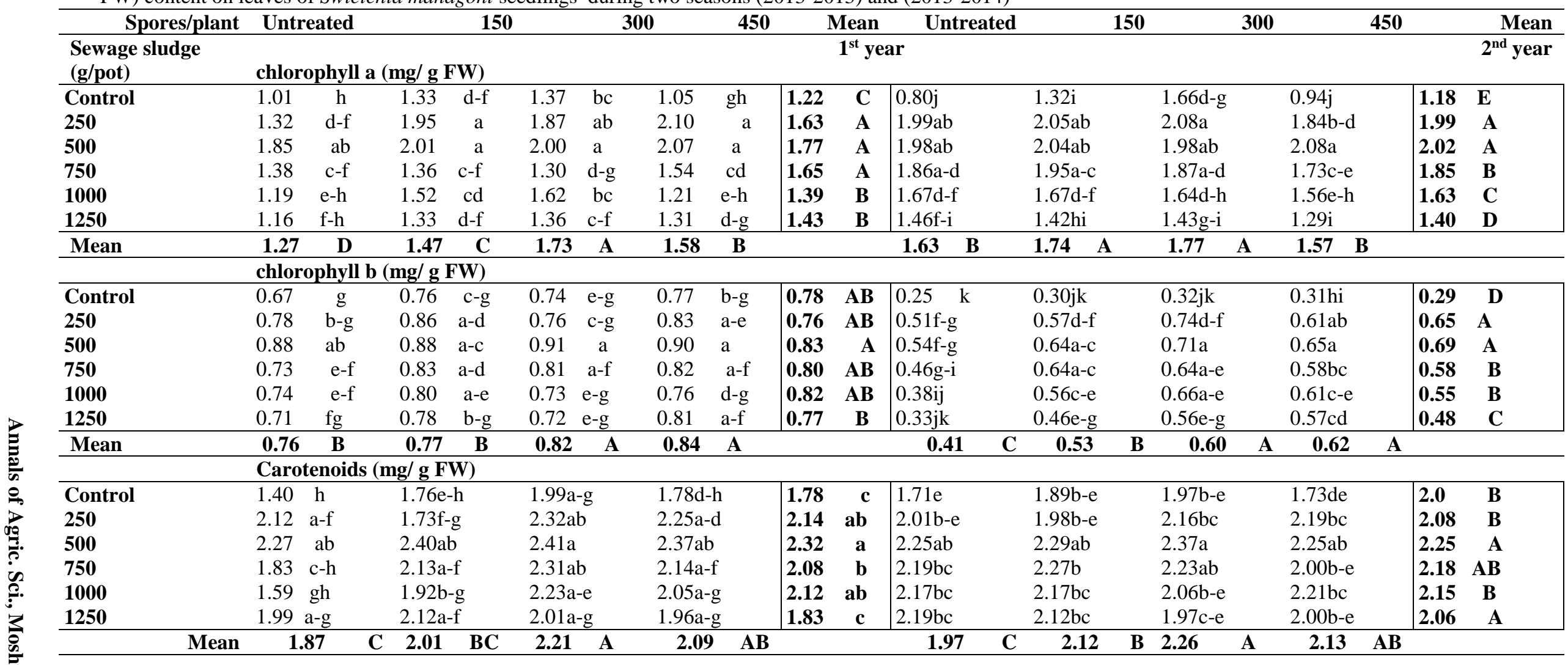


Table 7. Effects of interaction between sewage sludge and inoculation by endomycorrhizal fungi on heavy metals on leaves and roots of Swietenia mahagoni seedlings

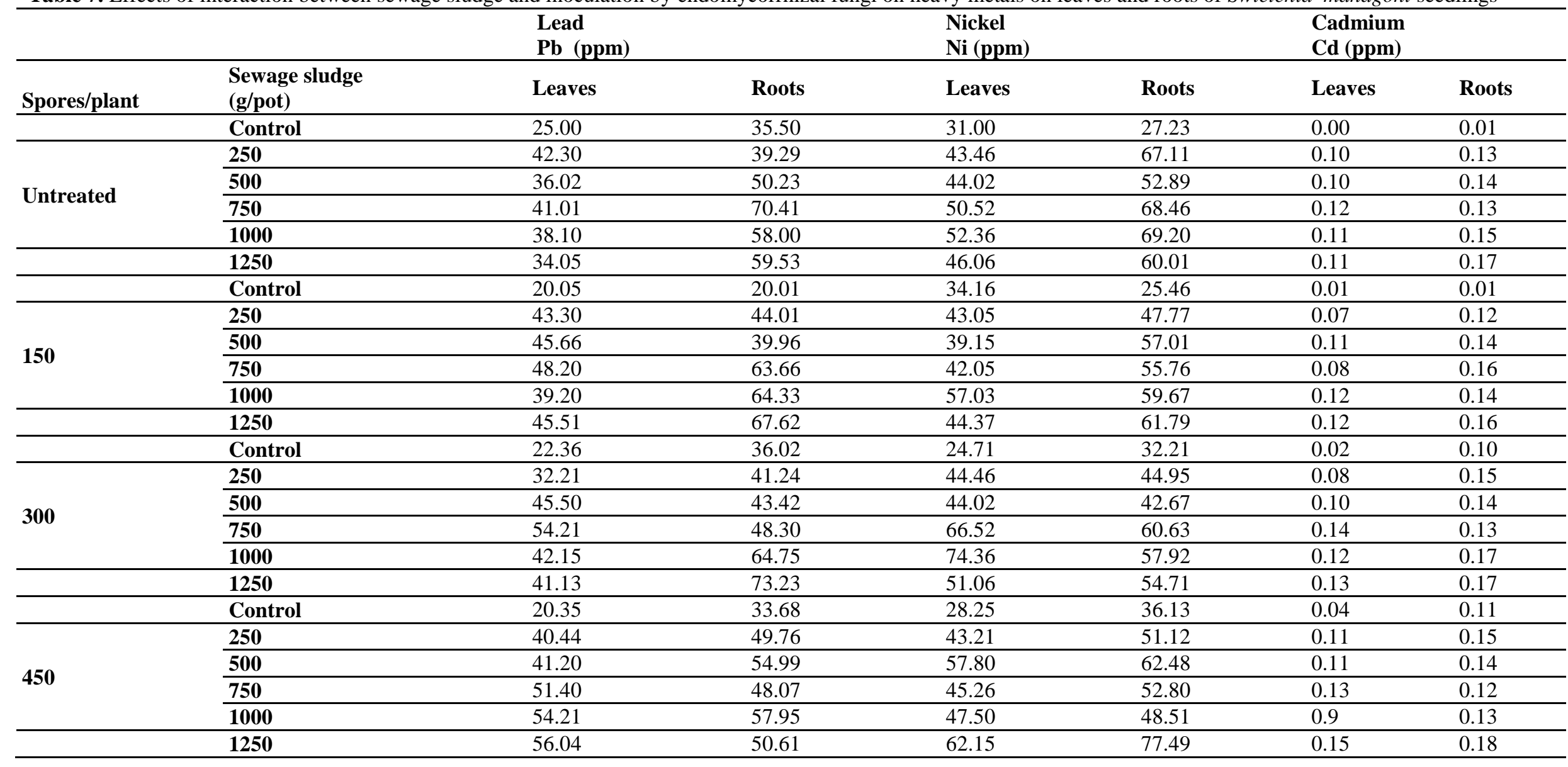


Table 8. Effects of interaction between sewage sludge and inoculation by endomycorrhizal fungi onMoisture content\% and Specific gravity (g/cm3) on stem of Swietenia mahagoni seedlings during two seasons (2013-2013) and 2013-2014)

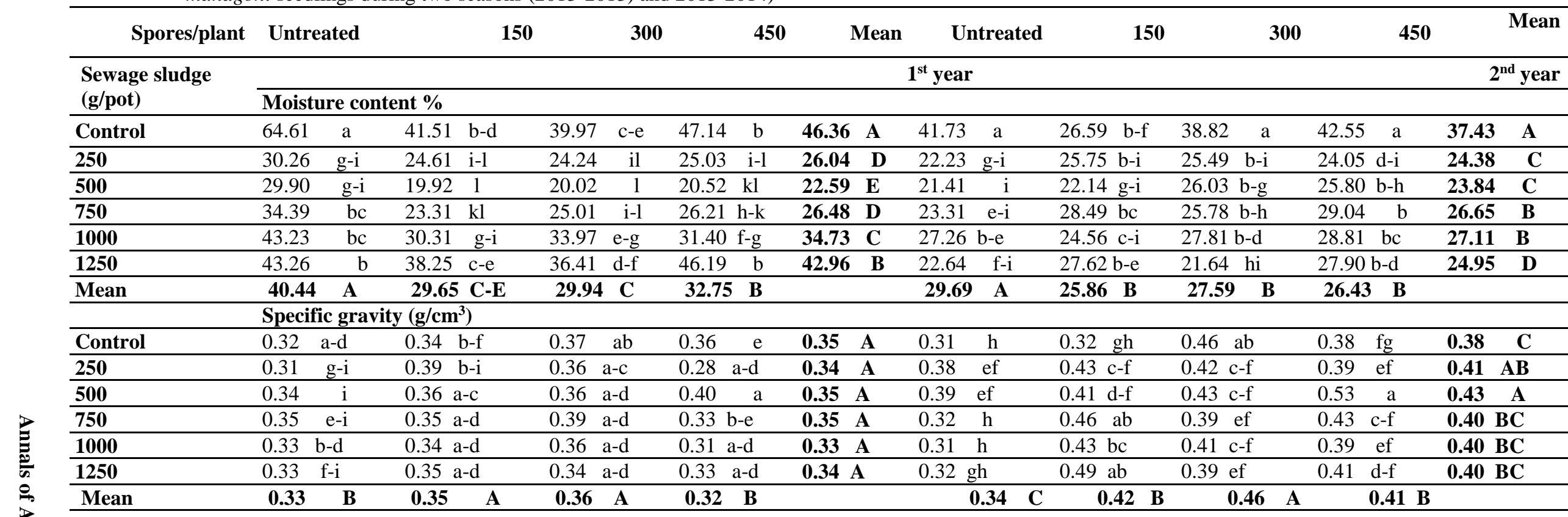




\section{References}

Allen, MF (1991). The ecology of mycorrhizae. Cambridge University Press, Cambridge, England.Cambridge Studies in Ecology Series

Almagrabi, O.A. and Abdelmoneim, T.S. (2012). Using of Arbuscular mycorrhizal fungi to reduce the deficiency effect of phosphorous fertilization on maize plants (Zea mays L.). Life Science Journal 9 (4):1648-1654

American Standard for Testing Materials (1989). Standard Test Methods for Specific Gravity of Wood and Wood - Base Materials. ASTMD, 2395 - 69, Philadelphia, P. A.

Augé, RM ; Stodola, AJW.; Gealy, DR. (1990). Turgor maintenance in Rosa foliage given three levels of nitrogen fertilization and subjected to drought. Journal of Environmental Horticulture 8: 108-112

Bhurat, M.R; Bavaskar, S.R; Agrawal, A.D. and Bagad, Y.M. (2011). Swietenia mahagoni Linn. - A Phytopharmacological Review. Asian J. Pharm. Res. 1: 1-4. 974- 979

Bose, S ; Jain, A. ; Rai, V .and Ramanathan, A. L. (2008). Chemical fractionation and transiocation of heavy metals in Canna indica L. grown in industrial waste amended soil. J. Hazardous Materials: 187 - 193

Carlot, M.; Giacomini, A. and Casella, S. ( 2002) . Aspects of plant-microbe interactions in heavy metals polluted soil. Acta Biotechnologica 22:1320

Clark, R.B.; and Zeto. S.K. ( 2000). Mineral acquisition by arbuscular mycorrhizal plants. Journal of Plant Nutrition 23: 867-902.

Dell, B. and Malajczuk, N. (1994). Boron deficiency in eucalypt plantations in China. Canadian Journal of Forest Research 24: 2409 2416

El-Baha, A. M. (2001). Response of Eucalyptus camaldulensis affected by thinning and sewage sludge or inorganic fertilizer on a poor quality site. Alexandria Journal of Agricultural Research, 46(1): $269-295$.

Kouloumbosa, V. N. ; Schaffer, A. and Corvini, P. F. X. (2008). Impact of sewage sludge conditioning and dewatering of the fate of nonylphenol in sludge-amended soils. Water Research, 42, pp. 3941 - 3951.

Landolt, E. and Kandeler, R. (1987) The family of Lemnaceae - a monographic study. 2,
Phytochemistry, physiology, application, bibliography. Veroff. Geobot. Inst. ETH, Zurich, $638 \mathrm{pp}$.

Marschner, H. and Dell, B. (1994). Nutrient uptake in mycorrhizal symbiosis. Plant and Soil 159: 89102.

Mazumdar, B.C. and Majumder, K. (2003). Methods of Physiochemical Analysis of Fruits. Daya Publishing House Delhi, India. pp. 123124

Newsham, K. K.; Fitter, A. H.; and Watkinson, A. R. (1995). Arbuscular mycorrhiza protect an annual grass from root pathogenic fungi in the field. Journal of Ecology, 991-1000.

Orwa, C. A.; Mutua, Kindt .R; Jamnadass, R S. and Anthony. (2009) Agroforestree Database:a tree reference and selection guide version 4.0) (http://www.worldagroforestry.org/sites/treedbs/tr eedatabases.asp

Panda, S.P.; Haldar, P.K.; Bera, S; Adhikary, S. and Kandar C.C. ( 2010). Antidiabetic and antioxidant activity of Swietenia mahagoni in streptozotocin-induced diabetic rats. Pharmaceutical Biology. 48: 974- 979

Page, A.L.; Miller, R.H. and. Keeneyeds D.R. (1982). Methods of Soil Analysis. Part 2. American Society of Agronomy, Madison, W.1.

Sahgal, G.; Ramanathan, S.; Sasidharan, S.; Mordi, M.N.; Ismail, S. and Mansor S. M. (2009). In Vitro Antioxidant and Xanthine Oxidase Inhibitory Activities of Methanolic Swietenia mahagoni Seed Extracts. Molecules. 14: 4476-4485.

Snedecor , G.N., and Cochran, W.G. (1967). Statistical methods. 6th ed. Iowa State Univ. Press, Ames, IA.

Spinosa, L. (2007).tewater sludge: a global overview of the current status and future prospects. IWA Publishing, London, $41 \mathrm{pp}$.

Trappe, J.M. (1982). Synoptic keys to the genera and species of zygomycetous mycorrhizal fungi. Phytopathology, 27(8): 1102-1108

Ya, Z. H.; Yang, Z. Y.; Chan , G. Y. S. and Wang M. H. (2001). Growth response of Sesbania rostrata and $S$. cannabina to sludge amended load zinc mine tailings : a green house study. Environment International, 26 (516): 449 - 455.

Zobel, M. Moora M., and Haukioja, E. (1997). Plant coexistence in the interactive environment: arbuscular mycorrhiza should not be out of mind. Oikos, 202-208 
تأتير الحمأة وفطريات الميكورهيزا الداخلية علي النمووالمحتوي الكيماوي ويعض الصفات الفيزيائية لشتلات الماهوجنى

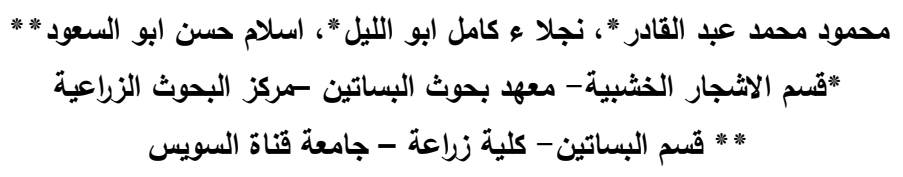

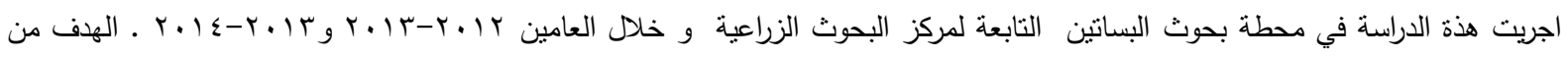

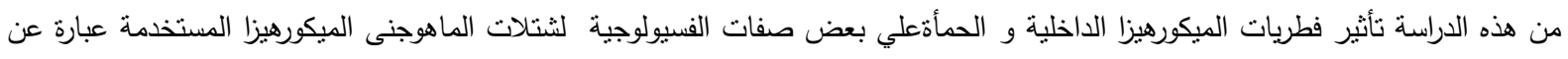

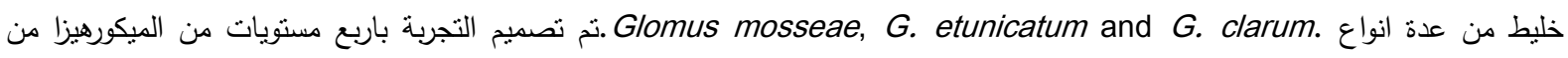

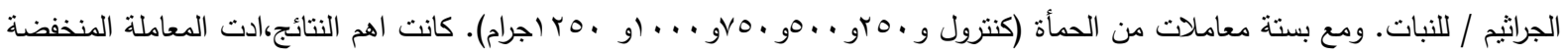

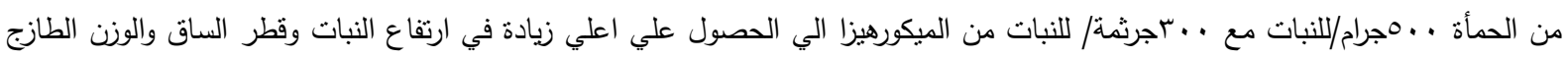

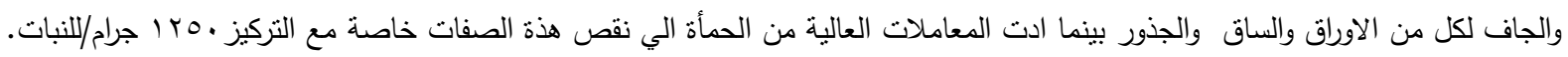

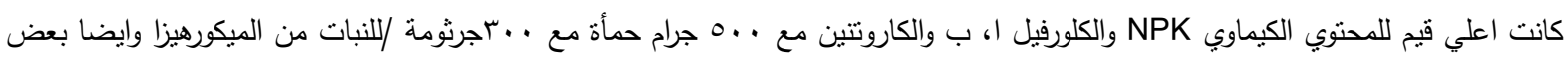
الصفات الفيزيائية. التوصية: يمكن الحصول علي افضل نمو للماهوجنى في الارضاي الرملية باضافة الميكورهيزا بمعدل . .باجرثومة/ للنبات مع .. مجرام من الحماة /نبات

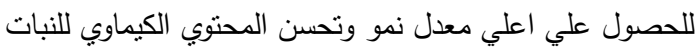

